\title{
SPECIAL NEEDS TEACHERS CAPACITY IN THE IMPLEMENTATION OF COMPETENCY BASED CURRICULUM IN PRIMARY SCHOOLS IN KENYA
}

\author{
Nelly C. Andiema (PhD) \\ School of Education \\ Kibabii University \\ P.O. Box 1699 - 50200, Bungoma, Kenya.
}

\begin{abstract}
This research looks at the capacity that special needs teachers in Kenyan primary schools have towards implementation of competency based curriculum in lower primary schools. Because of the abolishment of exclusion and adoption of inclusion policy, special needs learners are enrolled in mainstream schools and therefore have to be provided with the right and adequate support for their learning to take place. This study will survey a total of 83 public primary schools in Kapsaret Sub County, Kenya to determine the level of teacher capacity in the implementation of CBC. The sample will include special needs teachers teaching in those schools numbering to 69. Data collection was done through use of questionnaire for Special Needs Education Teachers in public primary schools. Data analysis will be performed using descriptive statistics for quantitative data and thematic content analysis for qualitative data. The study found out that: SNE teachers had moderate capacities in terms of understanding the $C B C$ curriculum and preparedness in implementing the CBC content in public primary schools in the study area. The enrolment of special needs learners was low and had not increased significantly and this was attributed to lack of adequate capacities by SNE teachers to provide required support to disabled learners. the paper recommends that SNE teachers need to be provided with specialised training on CBC implementation in inclusive setting, schools should ensure facilities and resources to support inclusive education are provided and TSC to increase special needs teachers numbers to more than one in primary schools. This article discusses findings, implications for the special education teacher preparation programmes in Kenyan teacher training institutions, and recommendations for future research
\end{abstract}

KEY WORDS: capacity, preparedness, competency, curriculum, special needs, education

\section{INTRODUCTION}

Inclusive education is fundamental to addressing the needs of diverse learners in schools across many world nations (Theeb, Muhaidat, \& Al-Zboon, 2014). In earlier times, special needs learners used to learn in special schools that were established contributing to their discrimination (Mukhopadhyay, 2014). Over time, renewed calls were coming from the United Nations level to abolish segregation of learners with disabilities and ensure they are included in the mainstream school systems (United Nations, 2011). One of the global policies supporting inclusion of special needs learners was Education For All (EFA) declarations made in Jomtien Thailand in the year 1990 
which called upon all countries to universalise provision of basic education. Further, in Salamanca, Spain in June 1994, the World Conference on Special Needs education reaffirmed the right to education for every child irrespective of disability to attend regular schools as a way of promoting inclusive education. With these developments, various countries became signatory of the international conference resolutions through ratification in their local policies including Kenya.

According to Friend and Bursuck (2011), the practice of inclusive education needs to include three basic elements in an integrated manner: (1) physical integration: all learners together in one class, (2) social integration: all pupils interact social, and (3) instructional integration: The learning program for all pupils belongs to the same curriculum, but modifications are required. As a school of inclusion, the realm of its implementation should have and be able to actualize the key elements, namely: (1) Community Based - (CB), (2) Barrier-Free - (BF), (3) Promotes Collaboration (PC), and (4) Promotes Equality - PE (Sunardi \& Imam, 2018).

In the effort to ensure primary education is implemented in inclusive classes, teachers should have the knowledge and confidence that special education in inclusive class settings will be useful in educating learners with disabilities. However, over the years, researchers have found that implementation of inclusive education from policy to practice is often met by many barriers in majority of developing countries (Zwane \& Malale, 2018). Lewis and Bagree (2013) noted that there is a global shortage of teachers who are sufficiently trained and motivated to include children with disabilities in regular schools. This has led to poor implementation of inclusion policy in primary schools across many countries of the world including Kenya.

This paper looks at the capacity of special needs teachers towards implementation of new competency based curriculum in public primary schools in Kenya. Government all over the world are trying to revise and/or build their teacher education programmes to ensure pre-service and in service teachers working on their teaching credentials are competent and ready to manage classrooms that are inclusive in nature (Alquraini \& Rao, 2017). Theeb, Muhaidat and Al-Zboon (2017) noted that the movement of teachers preparation based on the competencies became the most prominent field of study with the changes in curriculum. According to European Agency for Development in Special Needs Education (2010), the need for 'high quality' teachers equipped to meet the needs of all learners becomes evident to provide not only equal opportunities for all, but also education for an inclusive society. Reynolds (2009) indicated that it is the knowledge, beliefs and values of the teacher that are brought to bear in creating an effective learning environment for pupils, making the teacher a critical influence in education for inclusion and the implementation of curriculum goals. This means that teachers need capacity, confidence, knowledge and skills in implementing the new CBC curriculum in the country to meet the challenges that they will encounter in present inclusive classrooms.

Research studies conducted show that teachers possess different competencies and skills in delivery curriculum content in an inclusive classroom. Ineke, Mariya, Mireille and Sabine (2018) research in Luxembourg established that often are teachers ill 
prepared towards implementing new curriculum in an inclusive classroom with special needs children. In United States, Scheopner (2018) found out that the implementation of competency education in a K-12 classroom was not smooth despite it being implemented for six years because of inertial, technical, normative and political challenges. For instance, they found out that teachers faced difficulties in implementing grading and assessment systems brought about by new competency curriculum in New Hampshire secondary schools. A study conducted in Swaziland by Zwane and Malale (2018) found out that teachers' incompetence in identifying learners facing learning challenges in their classrooms are some barriers to inclusive policy implementation in schools. They found out that teacher capacity in ensuring that the curriculum fitted the needs and requirement of special need learners was very low. Coming to Kenya, a research by Tabot and Too (2017) found out that despite the primary teachers education (PTE) curriculum (in teachers training college) curriculum content was adequate in providing pre-service teachers with necessary special needs skills of identification and management in an inclusive classroom, the curriculum (PTE) failed to provide them with skills for improvisation of learning resources for ensuring individual educational plans (IEPs) for SEN were achieved. This point to the gaps in teacher capacity to adapt and prepare supplementary activities for learning in classrooms with an inclusive setting. This therefore departs from Tabot and Too focus by concentrating on the teachers teaching in public primary schools whereas they focused on pre-service teachers in teachers training colleges.

\section{Statement of the Problem}

The Kenya's Basic Education Curriculum Framework (KICD, 2017) provides two ways through which special needs education learners can receive classroom instructions. This is illustrated in Figure 1.

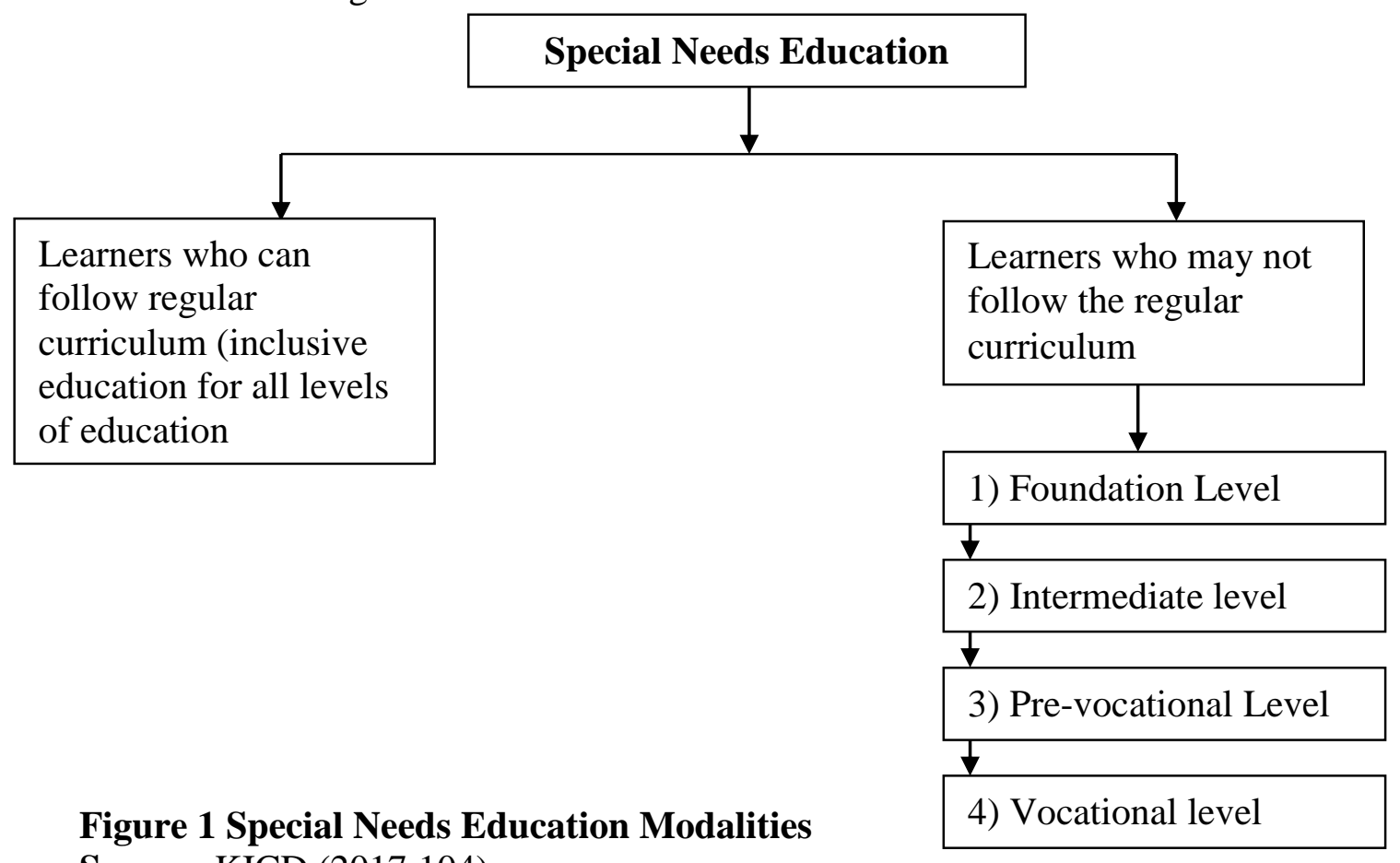


According to KICD, some learners with special needs may follow the same curriculum as learners without identified special needs. However, for some of these learners to access the regular curriculum, adaptation and modification may be necessary. Adaptations may include the substitution of curriculum content, removal of some content area, and the adaptation of teaching and learning strategies, resources and assessment. The curriculum may also be enriched in content for learners who are Gifted and Talented. This may be done by providing additional and advanced content, methodology, resources, time and assessment. Learners with special educational needs who may follow the regular curriculum may include those with:

\author{
i. Visual Impairment \\ ii. Hearing Impairment \\ iii. Physical Handicap \\ iv. Mild Cerebral Palsy \\ v. Learning Disabilities \\ vi. Autism \\ vii. Emotional and Behavioural Difficulties \\ viii. Communication Disorders and the \\ ix. Gifted and Talented
}

The category that this research focuses on is the learners who are enrolled in regular curriculum which emphasise on inclusive education. Research studies focusing on how special needs teachers are prepared to handle learners in inclusive settings in primary schools in the country remains inadequate and more so in Kapsaret Sub County, Kenya. This paper therefore looks at the capacity that SNE teachers have towards implementation of competency based curriculum in an inclusive setting.

\title{
Objectives of the Study
}

The following are the objectives of the paper:

(i) To determine SNE teachers' level of understanding of competency based curriculum content and implementation in an inclusive classroom

(ii) To assess SNE teachers' level of preparedness in implementing competency based curriculum content in an inclusive classroom

\section{Theoretical Framework}

This study is based on constructivism theory advanced by Brunner (1966) as cited by Tobias (2010). Constructivism is learning or meaning making theory that offers an explanation of the nature of knowledge and how human beings learn and capitalizes on learner's abilities to construct viable knowledge and fosters discovery learning (Kantar, 2013). An important aspect of constructivism is that individuals live in an environment of their own personal and their own experiences. Qiong (2010) opined that individual learning experiences performs a significant role in construction of this knowledge because knowledge cannot stay on its physical form and out of specific entity. Knowledge is acquired through involvement with the content rather than repetition or imitation. This result in a shift in paradigm from traditional teaching approach where teachers explain, analyse and introduce too much thus passive received knowledge by learners in class to focusing on how pupils learn. In relation to competency based 
curriculum, it was introduced in the country to improve learners' acquisition of competencies at the end of each unit, course or grade. This new curriculum requires that learners become active participants in learning rather than performing passive roles. This has resulted to transformation in teaching and learning activities in addition to assessment methods in the basic education system in the country. As a consequence, the $\mathrm{CBC}$ is designed in such a way that it would help learners to become knowledge constructors and emphasises the active role of teachers in the process of constructing this knowledge. Therefore, for teachers to ensure learning takes place in an inclusive classroom, they have to be competent and well prepared to ensure that $\mathrm{CBC}$ goals are attained.

\section{LITERATURE REVIEW}

\section{Competency based Curriculum}

Momanyi (2019) indicated that competency based curriculum on the other hand place emphasis on attainment of relevant skills as opposed to academic certificates.

The goal of competency education is to meet the needs of students more effectively by demanding student mastery of rigorous content and skills rather than measuring student learning by the amount of time a student has received instruction. Competency education demands that schools transform from a time-based system to a competencybased system (Scheopner, Brett, Cox \& Greller, 2018).

Competency based curriculum was introduced to Kenyan schools in 2017 as a pilot with the eventual adoption in January 2019. The competency-based curriculum was to be rolled out in January 2018 but was felt that the country was not prepared for its implementation (Momanyi \& Rop, 2019). Teachers haven't been sufficiently prepared while the support learning resources were still being developed. Competency based education in Kenya arrived at achieving the following seven core competencies; Communication and collaboration, critical thinking and problem solving, creativity and imagination, citizenship, digital literacy, learning to learn and self-efficacy. Learning of these competencies goes hand in hand with imparting of core values. These core values are; Love, responsibility, respect, unity, peace, patriotism, social justice and integrity. Learners are expected to master and incorporate these values and competencies for their application in life.

Mosha (2012) points out that qualified teachers with ample and appropriate knowledge and skills are one of the pre-conditions for a successful implementation of CBC. Therefore the need for changes in the instructional approaches, calls for the need to equip teachers (both in-service and pre-service) with the necessary competencies for handling new teaching paradigm. The implementation of $\mathrm{CBC}$ requires the use of new assessment strategies aligned with the new paradigm. To implement these changes it is necessary that all teachers become knowledgeable and equipped with new alternative approaches to assessment (Maclellan, 2004 in Makunja, 2015). In line with this, Sudsomboon (2010) points out that the successful realization of CBC heavily relies on the teachers, who are expected to give up their role as 'knowledge transmitters' and adopt the new role of 'coach' and instructional designer. Teachers are agents for change because of the role they play in implementing any curriculum reform. Studies have 
shown that curriculum reforms impact the school less, but they do influence teachers' practices in relation to their ability to shape policy. Teachers interpret, adapt and even translate reforms into practice (Utomo, 2005). The competence based curriculum requires teachers who are professionals, knowledgeable and competent in their work, particularly in implementing school curricula. If teachers are knowledgeable and conversant with the competence based curriculum they become an important aspect in improving the quality of education

\section{Inclusive Education}

Educating students with and without disabilities in the general classroom is becoming the current practice which is commonly known as inclusive education (Mukhopadhyay, Molosiwa \& Moswela, 2009). Inclusive education is perceived to be one of the means to increase educational access to large number of learners with disabilities. This means more children with disabilities will be placed in the mainstream classroom than before. In order to provide effective inclusive education for all learners, educators need to develop a different set of skills and knowledge than traditionally required by the profession.

Competency education has garnered support because a competency-based approach seeks to directly address issues of inequity to ensure that all students with disabilities and students from disadvantaged and different racial, ethnic, and linguistic backgrounds meet high expectations to prepare them for postsecondary success (Lewis et al., 2014; Sturgis, 2017).

\section{SNE Teachers Competence in Inclusive Education}

The success of inclusive education depends on adequate knowledge and skills of teachers (Florian, 2012). Whereas it is easier for policy makers to promote inclusive education in primary schools, the mere passage and implementation of policy is not a guarantee of success. This is because teachers need more than just positive attitudes in the translation of policy into practice. Teacher competency is the ability to plan, control and facilitate appropriate interaction in the classroom, while taking into account the different needs and abilities of learners (Dyson \& Squires, 2016). These competences are explained as a complex combination of different knowledge, skills, understanding, values, attitudes and desire which lead to effective, embodied human action in the world.

Competencies are the skills and knowledge that enable a teacher to be successful. The importance of teachers' competence for inclusive practice is evident in its effect on student learning. In general, research has indicated that specific cognitive abilities and personality characteristics determine to what extent teachers can be effective in delivering high quality instruction, which, in turn, fosters student learning (Ineke et al., 2018). These skills enable teachers to plan flexible instruction and to recognize the reality of differences between and in children, while yet being able to adapt learning goals, content, and the environment to the needs of individuals and the whole class (Agbenyega \& Deku, 2011). 
Teachers need the competencies to adapt teaching and learning to meet the needs of all children (Agbenyega \& Deku, 2011; Alhassan, 2012; Das, Gichuru, \& Singh, 2013). Competent teachers simultaneously translate theory into practice and consider the learner population and the socio-cultural contexts in which teaching and learning take place. One key teacher competency is the use of evaluation data to assess the attainment of goals set in Individualised Education Plan and to set new goals (Kusuma \& Ramdevi, 2013). Teachers may assess special needs student in the inclusive class by providing multiple test formats (Eredics, 2018). An effective teacher in an inclusive class will collect data through notes, checklists, sticky notes, and audio notes in order to keep track of student strengths and needs (Muvirmi, 2019).

Cate, Markova and Krischler (2018) reiterated the key areas of teacher competences as identification of children with special needs, planning to meet the needs, relevant material resources, instructional approaches, assessment and evaluation and effective collaboration with necessary stake holders. Teachers who have training in special needs education are pivotal in innovatively and collaboratively responding to the unique learning needs of all students (Muvirmi, 2019)

In the United States and Europe, it is generally stated that effective inclusive practice requires teachers to be able to deliver specialised instructional practices geared toward the individualized needs of all students (Watkins, 2012). Moreover, teachers should value learner diversity and be willing to support all learners (European Agency for Development in Special Needs Education, 2011). The lack of specific knowledge and training on inclusive methodologies discouraged general education teachers from supporting children with SEN in their classroom in Sri Lanka (Hettiarachchi \& Das, 2014). Majoko (2019) study found out that the perceived key competences for successful inclusion are screening and assessment, differentiation of instruction, classroom and behaviour management and collaboration. In Kenya, Kigen (2011) found out that teachers lack appropriate preparation and support in teaching children with disabilities in regular schools. This is a factor in the stated unwillingness of educators in many countries to support the inclusion of children with disabilities in their classes.

\section{MATERIALS AND METHODS}

The study methodology encompasses qualitative and quantitative approaches to data collection. A descriptive survey research design was used. The study area was Kapsaret Sub County, Uasin Gishu County, Kenya. All public primary schools in the sub county formed the target population with special needs education teachers teaching in mainstream sections of the schools. The focus of this study is to study on the competencies of SNE teachers towards the implementation of competency based curriculum in public primary schools in Kapsaret. Further, the competency based curriculum is implemented across all primary schools (private or public) in the country. Therefore the decision to choose Kapsaret Sub County is to act as representatives of the situation among SNE teachers in other areas of Kenya. A total of 83 SNE teachers formed the target population. Using a sample size formular, when the population is 83, confidence level at $95.0 \%$ and margin of error at 5\%, the sample size is 69 . Therefore, 69 SNE teachers from public primary schools in Kapsaret Sub County formed the 
sample. The selection of the sample was done randomly from the 83 using randomisation method. Collection of data was facilitated through use of questionnaire which was designed according to the study objectives. The questionnaires were distributed by the researcher in the sampled teachers within a span of two weeks after getting necessary approvals from Sub County Director of Education. Data analysis was performed using qualitative and quantitative methods. Quantitative data was coded and entered in electronic spreadsheets with the help of SPSS. Analysis of quantitative data was done using descriptive statistics. Open ended responses are provided in narrations in the next section.

\section{FINDINGS AND DISCUSSIONS}

The study collected data from 69 SNE needs teachers located in various public primary schools in Kapsaret Sub, County, Uasin Gishu Kenya. the respondents were asked to indicate their gender profile. Results are given in Figure 1.

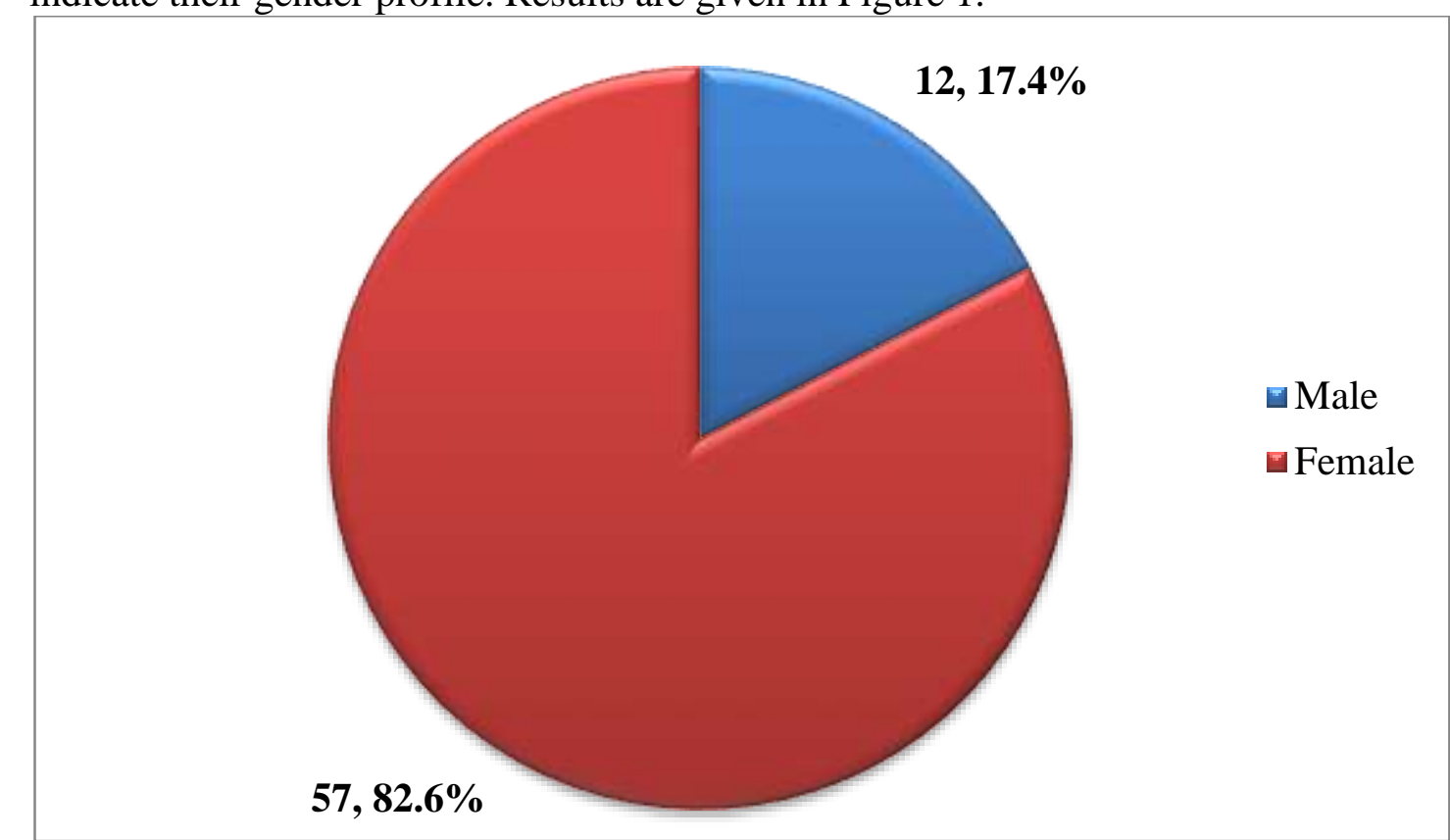

\section{Figure 1: Gender of SNE teachers}

Results show that majority $57(82.6 \%)$ of SNE teachers in public primary schools in the sub county are female whereas $12(17.4 \%)$ were male. this shows that the SNE profession attracts female teachers compared to male teachers. The study also requested the teachers to provide their age bracket indicators. Results are presented in Figure 2. 
Print ISSN: ISSN 2054-6351: Online ISSN: ISSN 2054-636X

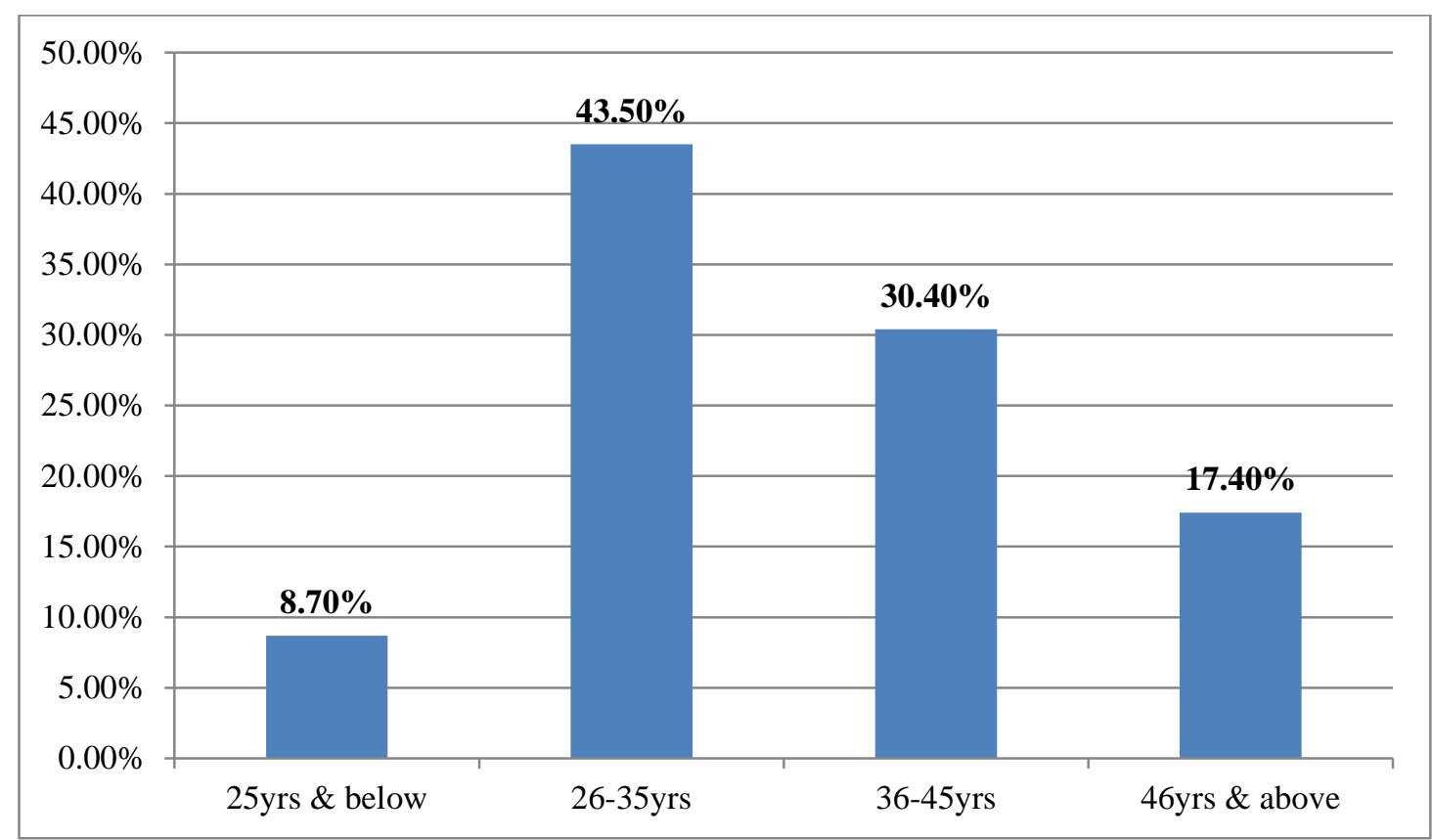

Figure 2: Teacher Age Bracket

Results show that $21(30.4 \%)$ of teachers were aged $36-45$ years, $6(8.7 \%)$ were aged 25 years and below, $30(43.5 \%)$ were aged $26-35$ years and $12(17.4 \%)$ were aged 46 years and above. This shows general distribution of respondents according to various ages to provide their experiences of handling special needs before and after the introduction of new competency based curriculum in public primary schools in Kapsaret Sub County, Kenya. The study also collected the SNE teachers academic qualifications which is indicated in Figure 3 below.

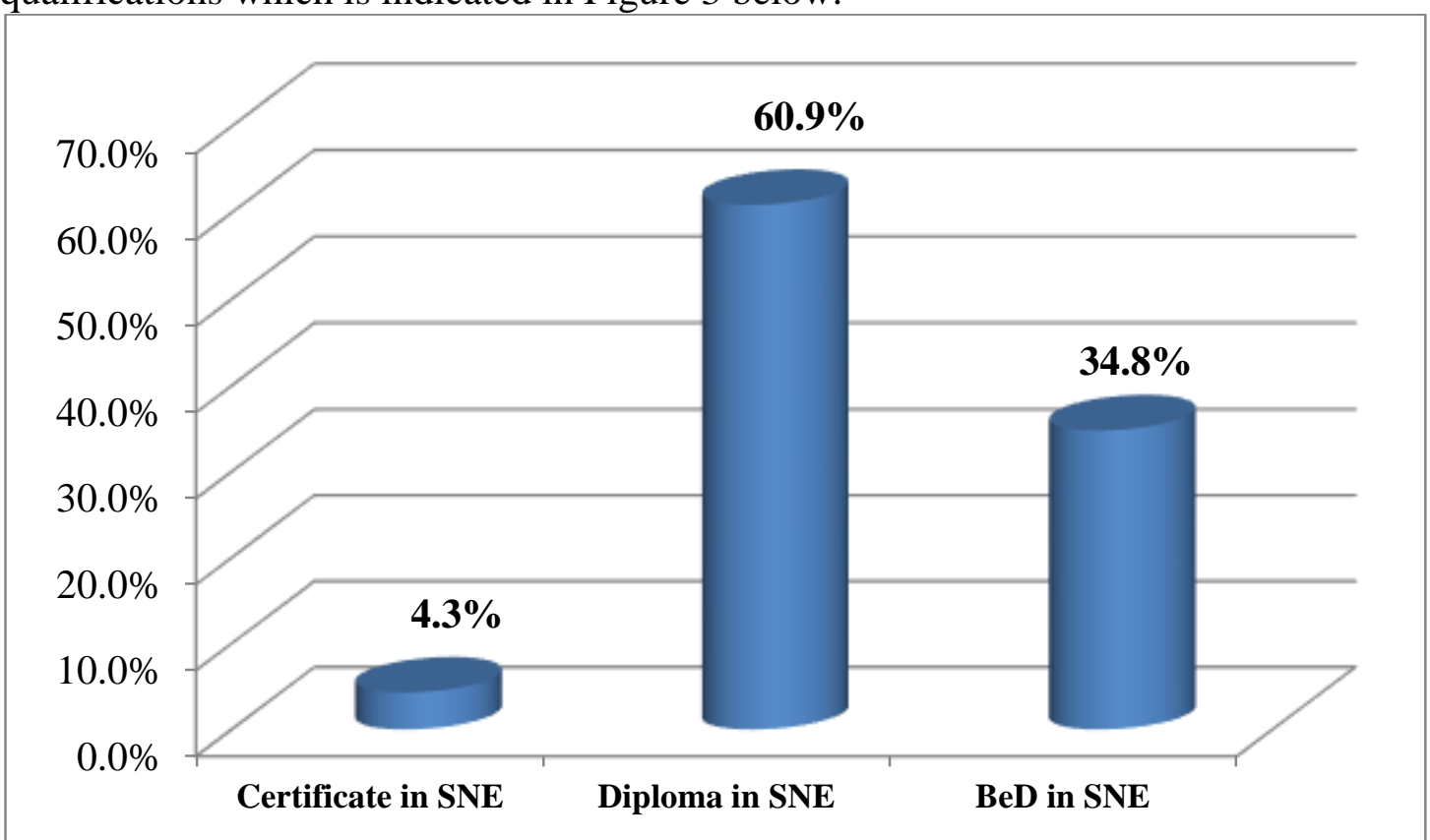

Figure 3 Distribution of SNE Teachers according to Education Qualifications 
Result shows that most $42(60.9 \%)$ of SNE teachers had attained diploma level of qualifications in handling special needs children. 24 (34.8\%) had undergraduate degree while $3(4.3 \%)$ had certificate degree aside from other qualifications required by Teachers Service Commission for them to teach in public primary schools. the experience of these teachers showed that they had a minimum of 2 years and a maximum of 15 years in teaching SNE learners in primary schools. the average years of experience was 7 years and this is adequate to understand their competencies in implementing the curriculum in their classrooms.

\section{Distribution of SNE Learners in Kapseret Sub County Public Primary Schools}

It was important for the researcher to investigate the distribution of special needs learners in schools in Kapsaret Sub County. Therefore, teachers were asked to provide information on the enrolment trends of SNE learners in their schools over a period of three years. Their feedback is given in Figure 4.

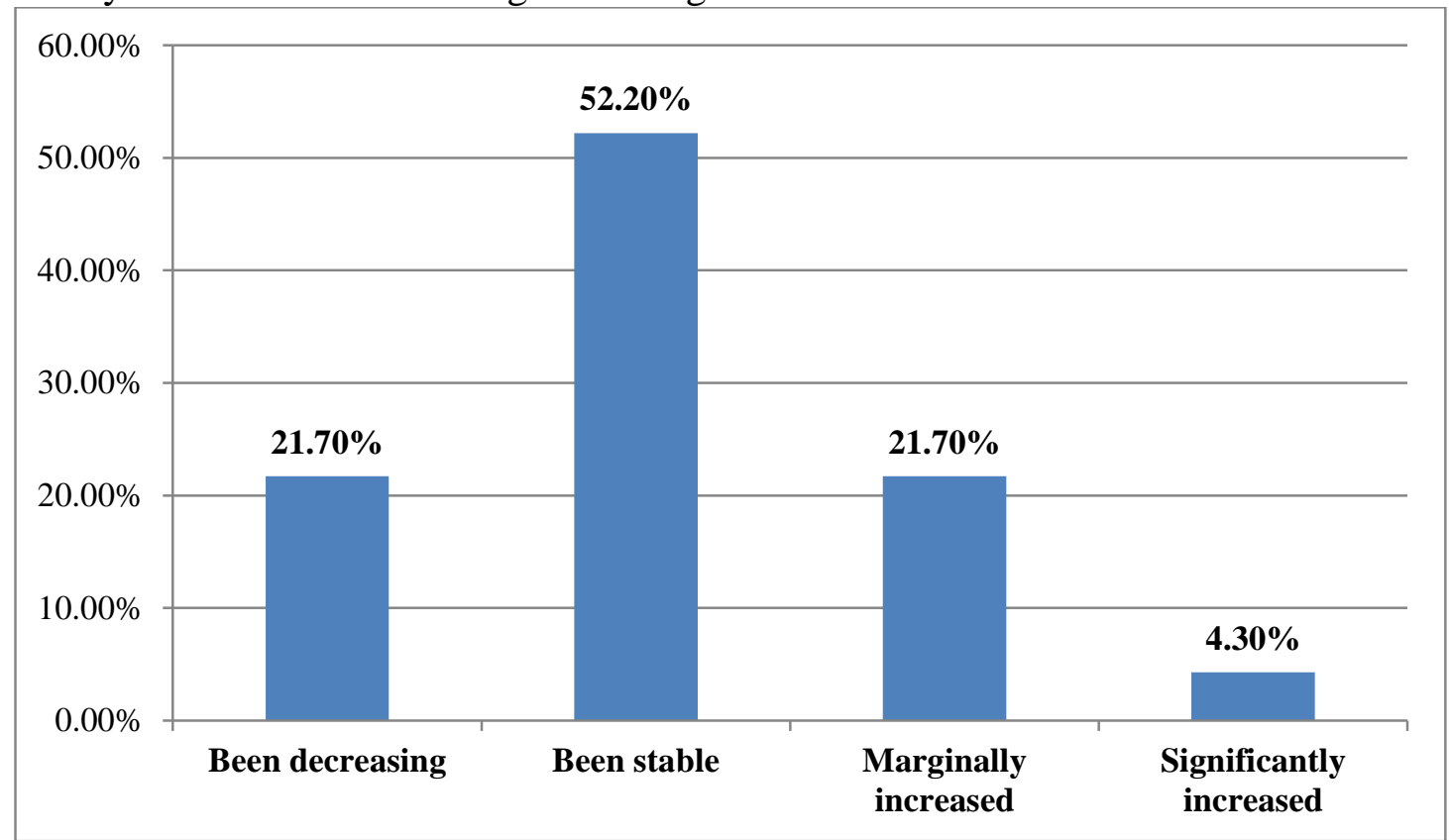

Figure 4 Enrolment Trends of SNE Learners in recent Years

Figure 4 outcomes shows that at least $36(52.2 \%)$ of indicated that the enrolment of SNE pupils has been stable in recent years, $15(21.7 \%)$ reported that it was decreasing, $15(21.7 \%)$ reported that it was marginally increasing and only $4.3 \%$ of teachers recorded significant increase in enrolment in their schools. the average statistics shows that enrolment of SNE learners has not recorded much improvements in recent years in public primary schools in Kapsaret Sub County. The research will therefore check whether the issues of teacher competency have a role in explaining the statistics. The SNE teachers were asked to indicate whether they had admitted various learners with special needs in their schools based on unique categories as listed in Table 1 below. 
Print ISSN: ISSN 2054-6351: Online ISSN: ISSN 2054-636X

Table 1: Category of Learners Admitted with Special Needs in Primary Schools

\begin{tabular}{llcccccc}
\hline & & \multicolumn{2}{c}{ Yes } & \multicolumn{2}{c}{ No } & \multicolumn{2}{c}{ Total } \\
\cline { 2 - 7 } & Category of special needs & Freq & Percent & Freq & Percent & Freq & Percent \\
\hline 1 & Learning Disabilities & 63 & 91.3 & 6 & 8.7 & 69 & 100.0 \\
2 & Communication Disorders & 60 & 87.0 & 9 & 13.0 & 69 & 100.0 \\
3 & Physical Handicapped & 57 & 82.6 & 12 & 17.4 & 69 & 100.0 \\
4 & Gifted and Talented & 45 & 65.2 & 24 & 34.8 & 69 & 100.0 \\
5 & Mild Cerebral Palsy & 33 & 47.8 & 36 & 52.2 & 69 & 100.0 \\
6 & Emotional and Behavioural & 30 & 43.5 & 39 & 56.5 & 69 & 100.0 \\
& Difficulties & & & & & & \\
7 & Visual Impairment & 21 & 30.4 & 48 & 69.6 & 69 & 100.0 \\
8 & Hearing Impairment & 18 & 26.1 & 51 & 73.9 & 69 & 100.0 \\
9 & Autism & 12 & 17.4 & 57 & 82.6 & 69 & 100.0 \\
\hline & Average statistics & $\mathbf{3 8}$ & $\mathbf{5 4 . 6}$ & $\mathbf{3 1}$ & $\mathbf{4 5 . 4}$ & $\mathbf{6 9}$ & $\mathbf{1 0 0 . 0}$ \\
\hline
\end{tabular}

Results shows that over $90.0 \%$ of pupils with learning disabilities have been admitted in public primary schools in the sub county followed by those with communication and speech disorders $(87.0 \%)$ and those who are physically handicapped (82.6\%). However, only children with autism (17.4\%), hearing impairment (26.1\%) and visual impairment $(30.4 \%)$ were found to be lowly admitted in public primary schools in the study area. These forms of disabilities require specialised assistive devices which are not for reach by majority of public primary schools in Kenya which are underfunded. Further, the study will investigate whether teacher capacity to teach the category of learners could be due to their competencies. Combined statistics shows that $54.6 \%$ of schools had admitted learners with various forms of disabilities whereas $45.4 \%$ of such children have not yet benefited from inclusive education practices in public primary school centres in Kapsaret Sub County.

\section{SNE Teachers Level of Understanding of Competency Based Curriculum Content in Implementation of Inclusive Education}

To ensure all learners irrespective of their disability receive basic primary education, all teachers including the special needs ones are required to ensure that they provide instruction to all learners. Through statements measured on a Likert scale of five; Veru High (5), High (4), Moderate (3), Low (2) and Very Low (1), the SNE teachers were asked to indicate their level of understanding of competency based curriculum towards inclusive education implementation in classrooms. The descriptive statistics are given in Table 2. 
Print ISSN: ISSN 2054-6351: Online ISSN: ISSN 2054-636X

Table 2 SNE Teachers Level of Understanding of CBC Content in Implementing Inclusive Education

\begin{tabular}{|c|c|c|c|c|}
\hline Responses & $\mathbf{N}$ & Mean & $\begin{array}{c}\text { Std. } \\
\text { Deviation }\end{array}$ & $\begin{array}{c}\text { Level of } \\
\text { understanding }\end{array}$ \\
\hline Understanding of CBC concept & 69 & 3.8551 & .98929 & \multirow{3}{*}{ High } \\
\hline $\begin{array}{l}\text { Understanding of the education } \\
\text { progression structure by CBC }\end{array}$ & 69 & 3.7681 & 1.10007 & \\
\hline $\begin{array}{l}\text { CBC allowing learners to progress } \\
\text { through classes upon demonstrating } \\
\text { mastery of prescribed competencies }\end{array}$ & 69 & 3.5797 & .92999 & \\
\hline $\begin{array}{l}\text { Awareness of the seven core } \\
\text { competencies that CBC seeks to } \\
\text { achieve in learners }\end{array}$ & 69 & 3.1884 & .98929 & \multirow[t]{3}{*}{ Moderate } \\
\hline $\begin{array}{l}\text { Understanding the method of } \\
\text { assessment required for learners in } \\
\text { CBC e.g. formative assessment }\end{array}$ & 69 & 3.0145 & 1.05011 & \\
\hline $\begin{array}{l}\text { Awareness of the core values that } \\
\text { learners are expected to master and } \\
\text { apply in life from CBC }\end{array}$ & 69 & 2.8406 & .91753 & \\
\hline $\begin{array}{l}\text { Training competencies on CBC in } \\
\text { inclusive setting }\end{array}$ & 69 & 2.4203 & 1.00595 & \multirow[t]{2}{*}{ Low } \\
\hline $\begin{array}{l}\text { Understanding of behaviour } \\
\text { management among special needs } \\
\text { learners in regular classrooms }\end{array}$ & 69 & 2.3623 & .92309 & \\
\hline Valid N (listwise) & 69 & 3.1286 & 0.98817 & Moderate \\
\hline
\end{tabular}

Research outcomes shows that teachers exhibited various level of understanding of the concepts of $\mathrm{CBC}$ towards implementation in an inclusive classroom setting. For example, teacher understanding of the $\mathrm{CBC}$ concept was highly ranked $(\mathrm{M}=3.85$ and $\mathrm{SD}=0.98)$, understanding of the progression structure under $\mathrm{CBC}(\mathrm{M}=3.76$ and $\mathrm{SD}=1.10$ ) and being aware that progress of learners from one grade to another is when they demonstrate mastery of prescribed competencies. The above result shows that very few teachers possessed very high competencies with regard to the eight statements on CBC implementation in inclusive setting. Moderate level of understanding that SNE teachers exhibited related to; awareness of seven core competencies of CBC (M=3.18 and $\mathrm{SD}=0.98$ ), understanding assessment methods like formative assessment in CBC $(\mathrm{M}=3.01$ and $\mathrm{SD}=1.05)$ and awareness of core values expected learners to master and apply from $\mathrm{CBC}(\mathrm{M}=2.84$ and $\mathrm{SD}=0.91)$. This means that $\mathrm{SNE}$ teachers' exhibit moderate level of understanding on the above contents of $\mathrm{CBC}$ and which could influence their effective curriculum delivery to special needs children enrolled in their schools. Further, results revealed teachers low level of understanding of competencies relating to the implementation of $\mathrm{CBC}$ in inclusive setting $(\mathrm{M}=2.42$ and $\mathrm{SD}=1.00)$ and understanding of behavioural management among special needs children in their classrooms $(\mathrm{M}=2.36$ and $\mathrm{SD}=0.92)$. Composite data shows that the teachers level of understanding of $\mathrm{CBC}$ concepts implementation in inclusive setting was found to be average $(\mathrm{M}=3.12$ and $\mathrm{SD}=0.98)$. This could explain the low level of enrolment of 
special needs learners in public mainstream primary schools in Kapsaret Sub County, Kenya.

After establishing SNE teachers' level of understanding of CBC implementation in an inclusive setting, the researcher went further to determine their level of preparedness in implementing the curriculum in their classrooms. Through eight statements measured on a Likert scale of five; Strongly Disagree (1), Disagree (2), Undecided (3), Agree (4) and Strongly Agree (5), the teachers were asked to provide their level of preparedness. Findings are summarized in Table 3.

Table 3: SNE Teachers Level of Preparedness in Implementing CBC in Inclusive Classroom

\begin{tabular}{|c|c|c|c|c|c|c|c|}
\hline $\begin{array}{l}\text { Preparednes } \\
\text { S }\end{array}$ & SD & D & $\mathbf{U}$ & $\mathbf{A}$ & SA & $\mathbf{M}$ & SDV \\
\hline $\begin{array}{l}\text { I can identify } \\
\text { learners with } \\
\text { special needs } \\
\text { in my } \\
\text { classroom } \\
\text { during } \\
\text { teaching }\end{array}$ & $\begin{array}{c}0 \\
(0.0 \%)\end{array}$ & $\begin{array}{c}11 \\
(15.9 \% \\
)\end{array}$ & $\begin{array}{c}12 \\
(17.4 \% \\
)\end{array}$ & $\begin{array}{c}26 \\
(37.7 \% \\
)\end{array}$ & $\begin{array}{c}20 \\
(29.0 \% \\
)\end{array}$ & $\begin{array}{c}3.797 \\
1\end{array}$ & $\begin{array}{c}1.0372 \\
4\end{array}$ \\
\hline $\begin{array}{l}\text { I adapt my } \\
\text { teaching and } \\
\text { learning to } \\
\text { meet the } \\
\text { needs of all } \\
\text { children }\end{array}$ & $\begin{array}{c}3 \\
(4.3 \%)\end{array}$ & $\begin{array}{c}12 \\
(17.4 \% \\
)\end{array}$ & $\begin{array}{c}14 \\
(20.3 \% \\
)\end{array}$ & $\begin{array}{c}30 \\
(43.5 \% \\
)\end{array}$ & $\begin{array}{c}3 \\
(4.3 \%)\end{array}$ & $\begin{array}{c}3.463 \\
8\end{array}$ & $\begin{array}{c}1.0789 \\
4\end{array}$ \\
\hline $\begin{array}{l}\text { I do plan to } \\
\text { meet the } \\
\text { needs of each } \\
\text { children in an } \\
\text { inclusive } \\
\text { classroom }\end{array}$ & $\begin{array}{c}3 \\
(4.3 \%)\end{array}$ & $\begin{array}{c}8 \\
(11.6 \% \\
)\end{array}$ & $\begin{array}{c}26 \\
(37.7 \% \\
)\end{array}$ & $\begin{array}{c}30 \\
(43.5 \% \\
)\end{array}$ & $2(2.9 \%$ & $\begin{array}{c}3.289 \\
9\end{array}$ & .87618 \\
\hline $\begin{array}{l}\text { I organise for } \\
\text { use of } \\
\text { relevant } \\
\text { material } \\
\text { resources in } \\
\text { an inclusive } \\
\text { classroom to } \\
\text { meet CBC } \\
\text { objectives }\end{array}$ & $\begin{array}{c}10 \\
(14.5 \% \\
)\end{array}$ & $\begin{array}{c}26 \\
(37.5 \% \\
)\end{array}$ & $\begin{array}{c}20 \\
(29.0 \% \\
)\end{array}$ & $\begin{array}{c}7 \\
(10.1 \% \\
)\end{array}$ & $\begin{array}{c}6 \\
(8.7 \%)\end{array}$ & $\begin{array}{c}2.608 \\
7\end{array}$ & $\begin{array}{c}1.1274 \\
3\end{array}$ \\
\hline $\begin{array}{l}\text { Teaching } \\
\text { methods that } \\
\text { I use meets } \\
\text { the needs of } \\
\text { all learners }\end{array}$ & $\begin{array}{c}3 \\
(4.3 \%)\end{array}$ & $\begin{array}{c}15 \\
(21.7 \% \\
)\end{array}$ & $\begin{array}{c}36 \\
(52.2 \% \\
)\end{array}$ & $\begin{array}{c}12 \\
(17.4 \% \\
)\end{array}$ & $\begin{array}{c}3 \\
(4.3 \%)\end{array}$ & $\begin{array}{c}2.956 \\
5\end{array}$ & .86492 \\
\hline
\end{tabular}




\begin{tabular}{|c|c|c|c|c|c|c|c|}
\hline $\begin{array}{l}\text { irrespective } \\
\text { of their } \\
\text { disability }\end{array}$ & & & & & & & \\
\hline $\begin{array}{l}\text { I collaborate } \\
\text { with other } \\
\text { teachers and } \\
\text { stakeholders } \\
\text { to ensure } \\
\text { CBC goals } \\
\text { for inclusive } \\
\text { classroom are } \\
\text { attained }\end{array}$ & $\begin{array}{c}2 \\
(2 / 9 \%)\end{array}$ & $\begin{array}{c}2 \\
(2 / 9 \%)\end{array}$ & $\begin{array}{c}21 \\
(30.4 \% \\
)\end{array}$ & $\begin{array}{c}30 \\
(43.5 \% \\
)\end{array}$ & $\begin{array}{c}14 \\
(20.3 \% \\
)\end{array}$ & $\begin{array}{c}3.753 \\
6\end{array}$ & .91404 \\
\hline $\begin{array}{l}\text { I am always } \\
\text { willing to } \\
\text { support the } \\
\text { diverse needs } \\
\text { and } \\
\text { requirements } \\
\text { of learners in } \\
\text { class }\end{array}$ & $\begin{array}{c}0 \\
(0.0 \%)\end{array}$ & $\begin{array}{c}4 \\
(5.8 \%)\end{array}$ & $\begin{array}{c}16 \\
(23.2 \% \\
)\end{array}$ & $\begin{array}{c}24 \\
(34.8 \% \\
)\end{array}$ & $\begin{array}{c}25 \\
(36.2 \% \\
)\end{array}$ & $\begin{array}{c}4.014 \\
5\end{array}$ & .91544 \\
\hline $\begin{array}{l}\text { I can use } \\
\text { differentiated } \\
\text { instruction to } \\
\text { ensure CBC } \\
\text { curriculum } \\
\text { goals are } \\
\text { attained in } \\
\text { inclusive } \\
\text { classroom }\end{array}$ & $\begin{array}{c}2 \\
(2.9 \%)\end{array}$ & $\begin{array}{c}11 \\
(15.9 \% \\
)\end{array}$ & $\begin{array}{c}15 \\
(21.7 \% \\
)\end{array}$ & $\begin{array}{c}27 \\
(39.1 \% \\
)\end{array}$ & $\begin{array}{c}14 \\
(20.3 \% \\
)\end{array}$ & $\begin{array}{c}3.579 \\
7\end{array}$ & $\begin{array}{c}1.0765 \\
7\end{array}$ \\
\hline $\begin{array}{l}\text { Composite } \\
\text { score }\end{array}$ & & & & & & $\begin{array}{c}3.433 \\
0\end{array}$ & $\begin{array}{c}0.9863 \\
5\end{array}$ \\
\hline
\end{tabular}

Key: SD-Strongly Disagree, D-Disagree, U-Undecided, A-Agree and SA-Strongly Agree, SDV-Standard Deviation and M-Mean.

Results show that 26 (37.7\%) of SNE teachers agreed and $20(29.0 \%)$ strongly agreed that they were in a position to identify learners with special needs during teaching and learning in classroom. The result therefore show that $66.7 \%$ of SNE teachers have the capacity to identify special needs learners while teaching so that they can provide appropriate interventions to enhance their learning in schools. Findings reveals that 30 (43.5\%) of SNE teachers agreed that they always adapt their teaching and learning strategies to meet the needs of all children, 14 (20.3\%) were undecided while 12 $(17.4 \%)$ disagreed. The result shows that teachers do not regularly adapt their teaching strategies to realise the needs of all children and this could be because of lack of special needs children in their classrooms or even inadequate competencies on methods of instructions to be used in inclusive classroom setting. Findings showed that 30 (43.5\%) agreed that they do plan to meet the needs of each children in an inclusive classroom whereas $26(37.7 \%)$ were undecided. The result shows that at times $(M=3.28$ and 
$\mathrm{SD}=0.87) \mathrm{SNE}$ teachers did at times prepare to meet the individual instructional needs of each pupil in classroom. The lack of regular plan to meet the individual plans for each child in classroom is due to teacher workload and high pupil: teacher ratio, which makes it difficult for the SNE teacher to meet individual needs of special needs children as they are also engaged in regular classroom lessons. Study results showed that 26 (37.5\%) of teachers disagreed that they organised for use of relevant material resources in an inclusive classroom to meet the objectives of CBC with only $7(10.1 \%)$ agreeing to do so and $6(8.7 \%)$ strongly disagreeing. This shows that more than half $(52.0 \%)$ of SNE teachers do not have the capacity to organise for provision of relevant assistive devices to enable implementation of inclusive education in their schools. This could be due to the cost associated with procurement of the assistive devices, lack of expertise in operating assistive devices and poor parental support for their children in school. Research findings revealed that more than half 36 (52.2\%) of SNE teachers were undecided that the teaching methods they were using met the needs of all learners irrespective of their disability. This means that because of high learner population, it is impossible for a majority of teachers to know the effectiveness of teaching methods that they use in meeting the instructional needs of their population. Findings showed that $30(43.5 \%)$ of SNE teachers agreed and $14(20.3 \%)$ strongly agreed that they collaborated with other teachers and stakeholders to ensure CBC goals for inclusive classrooms are attained. This means that SNE teachers collaborate with other regular teachers among other stakeholders to ensure the needs of inclusive special children are taken into consideration. When asked as to whether they are always willing to support the diverse needs and requirements of learners in class, 4 (5.8\%) disagreed, 16 (23.2\%) were undecided, 24 (34.8\%) agreed and $25(36.2 \%)$ strongly agreed. Result therefore shows that over $71.0 \%$ of SNE teachers were willing to aid learners with diverse special needs to receive the required competencies of CBC. Research result also showed that $27(39.1 \%)$ agreed and $14(20.3 \%)$ strongly agreed that they use differentiated instruction to ensure $\mathrm{CBC}$ curriculum goals are attained in schools. The research shows that $59.4 \%$ use differentiated instruction while $18.8 \%$ did not use the method in ensuring the goals of $\mathrm{CBC}$ are attained in inclusive classrooms in public primary schools in Kapsaret Sub County, Kenya.

\section{Challenges Experienced by SNE teachers in inclusive classroom setting}

Through open-ended question, the SNE teachers were asked to highlight some of the challenges that they experienced in implementing new $\mathrm{CBC}$ curriculum in public primary schools in Kapsaret Sub County, Kenya. One Teacher No. 3 mentioned that:

"Lack of facilities e.g. hearing aids, limited time to attend to individual learners."

Another teacher No. 66 remarked that:

"Inadequate training provided to SNE teachers to ensure that the goals of $C B C$ for special needs category of learners are realised."

Moreover, teacher No. 44 indicated the following as challenges they experienced:

"Inadeqate support from school administration, parents, societal stigma to special needs learners, lack of expertise in using assistive devices and inadequate instructional resources for $C B C$ implementation in an inclusive setting." 
The above response shows that significant challenges were being experienced by SNE teachers in public primary schools in Kapsaret Sub County, Kenya.

\section{CONCLUSION AND RECOMMENDATIONS}

This study set out to determine the capacity of special needs teachers towards implementation of new competency based curriculum in an inclusive classroom setting. The study was conducted among SNE teachers from various public primary schools in Kapsaret Sub County, Uasin Gishu County, Kenya. Research results showed that all teachers teaching in the sub county had the necessary academic qualifications to teach special needs children in an inclusive and excusive classroom setting. However, their capacity to understand the goals of the $\mathrm{CBC}$ curriculum varied as they were to have moderate level of understanding, which influenced their delivery of $\mathrm{CBC}$ curriculum in school. The limited understanding of the contents of CBC curriculum in inclusive setting also contributed to low enrolment of such learners in schools against the policy of inclusion. SNE teachers were found to be aware of CBC, progression structure and methods of assessment. However, they were found to have low understanding in behavioural management core competencies that $\mathrm{CBC}$ seeks to achieve for special needs learners. With regard to their level of preparation in classroom, the study found out that teachers were in a good position to identify the unique special needs of each learner but did not regularly prpvded individual teaching strategies to cater for the needs of special needs children. The lack of teacher preparation was found to be one of the reasons for low enrolment of special needs learners especially those with severe and diverse forms of disabilities like autism, hearing, blind and those with emotional and behavioural difficulties. In general, the study found out that special needs teachers had moderate capacity to implement $\mathrm{CBC}$ curriculum in inclusive setting in public primary schools in the study area. The paper therefore recommends that regular and proper training to be provided to SNE teachers by KICD and MOE, there is need for schools administration to work with government and parents to provide assistive devices and instructional resources and TSC needs to increase the distribution of special needs teachers in public primary schools to more than one.

\section{References}

European Agency for Development in Special Needs Education (2010). Teacher Education For Inclusion: International Literature Review. Odense, Denmark: European Agency for Development in Special Needs Education.

Ineke, M.P., Mariya, M., Mireille, K. \& Sabine, K-S. (2018). Promoting Inclusive Education: The Role of Teachers' Competence and Attitudes. Insights into Learning Disabilities, 15(1), 49 - 63.

Scheopner, A.T., Brett, J., Cox, J. \& Greller, S. (2018). Competency Education Implementation: Examining the Influence of Contextual Forces in Three New Hampshire Secondary Schools. AERA Open, 4(2), $1-13$. DOI: $10.1177 / 2332858418782883$.

Zwane, S.L. \& Malale, M.M., (2018). 'Investigating barriers teachers face in the implementation of inclusive education in high schools in Gege branch, Swaziland', African Journal of Disability 7(0), a391. https://doi.org/ 10.4102/ajod.v7i0.391 
Tabot B. A. \& Too J.K. (2017). Integration of Special Needs Education in Primary Teacher Education Curriculum and teacher trainees' skills for instructional efficacy in Kenya. International Journal of Education and Research, 5(7), 23 36. 